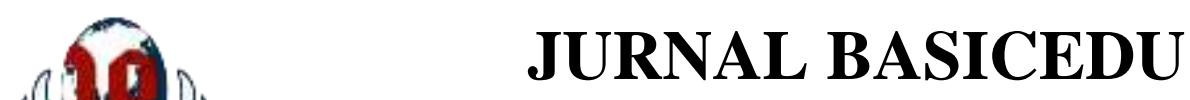

Volume 5 Nomor 6 Tahun 2021 Halaman 5671 - 5681

Research \& Learning in Elementary Education

https://jbasic.org/index.php/basicedu

\title{
Mendesain Pembelajaran PKn dan IPS yang Inovatif dan Kreatif dengan Menggunakan Model Pembelajaran pada Tingkat Sekolah Dasar
}

\author{
Selfi Rahmi Andini ${ }^{1 凶}$, Vianes Muliza Putri' ${ }^{2}$, Meila Yufriana Devi ${ }^{3}$, Yeni Erita \\ Universitass Negeri Padang, Indonesia ${ }^{1,2,3,4}$ \\ E-mail: selfirahmiandini1077@gmail.com ${ }^{1}$, vianesmulizap@gmail.com² ${ }^{2}$, meilayufrianadevi1@ gmail.com $^{3}$, \\ yenierita@fip.unp.ac.id ${ }^{4}$
}

\begin{abstract}
Abstrak
Desain pembelajaran dirancang agar bisa proses pembelajaran menjadi lancar. Penelitian ini bertujuan untuk mengeksplorasi atau menganalisis tentang pentingnya guru untuk mendesain pembelajaran ips dan pkn yang inovatif dan kreatif pada pembelajaran di SD. Pembelajaran yang inovatif akan membuat siswa tertarik pada pembelajaran dan memicu munculnya kreatifitas pada siswa. Kriteria desain pembelajaran yang diharapkan disini adalah berpusat pada siswa. Mendesain pembelajaran ini harus diawali dengan studi pendahuluan mengenai siswa. Beberapa hal yang perlu dipahami tentang siswa yaitu kemampuan dasar dan gaya belajar yang masih banyak siswa tidak tertarik mengikuti pembelajaran. Pendekatan yang digunakan dalam penelitian ini ialah studi literatur. Dimana peneliti menganalisis sejumlah jurnal maupun artikel dari penelitian terdahulu yang relevan. Pengumpulan data dilakukan melalui jejak online dengan mencari jurnal dan artikel melalui google schoolar Hasil analisis dari berbagai jurnal yang ditemukan menunjukkan bahwa mendesain pembelajaran ips dan pkn yang inovatif dan kreatif perlu dilakukan oleh seorang guru dalam memberikan pembelajaran untuk siswa Sekolah Dasar khusuna pada pembelajaran IPS dan PKn.
\end{abstract}

Kata Kunci: Desain pembelajaran, IPS PKn, Model Pembelajaran.

\section{Abstract}

The learning design is structured to help the student learning process. This study aims to explore or analyze the importance of teachers in designing innovative and creative social studies learning in elementary school. Innovative learning will make students interested in learning and trigger the emergence of creativity in students. The expected learning design criteria here are student-centered. Thus, designing learning needs to begin with conducting a preliminary study of students. Some things that need to be understood about students are basic abilities and learning styles that still many students are not interested in participating in learning. The approach used in this research is qualitative with the type of research being a literature study. Where the researchers analyzed a number of journals and articles from relevant previous studies. Data collection was carried out through an online trail by searching for journals and articles through google schoolar. The results of the analysis of various journals found showed that designing innovative and creative social studies learning for Civics needs to be done by a teacher in providing learning for special elementary school students in social studies and Civics learning.

Keywords: learning design, IPS PKn, learning model.

Copyright (c) 2021 Selfi Rahmi Andini, Vianes Muliza Putri, Meila Yufriana Devi, Yeni Erita

Corresponding author :

Email : selfirahmiandini1077@gmail.com

DOI $:$ https://doi.org/10.31004/basicedu.v5i6.1760

ISSN 2580-3735 (Media Cetak)

ISSN 2580-1147 (Media Online)

Jurnal Basicedu Vol 5 No 6 Tahun 2021

p-ISSN 2580-3735 e-ISSN 2580-1147 
5672 Mendesain Pembelajaran PKn dan IPS yang Inovatif dan Kreatif dengan Menggunakan Model Pembelajaran pada Tingkat Sekolah Dasar - Selfi Rahmi Andini, Vianes Muliza Putri, Meila Yufriana Devi, Yeni Erita

DOI: https://doi.org/10.31004/basicedu.v5i6.1760

\section{PENDAHULUAN}

Latihan proses pembelajaran dikoordinasikan sebagai tenaga yang sadar dan teratur sebagai pekerjaan untuk bekerja pada sifat SDM dengan tujuan agar mereka dapat sampai pada ruang hasil pembelajaran, baik dalam domain persepsi, kehangatan dan domain psikomotorik sebagai perubahan perspektif dan perilaku. Jadi setiap pendirian instruktif harus diawasi oleh individu yang memiliki kemampuan dalam membuat rencana atau desain pembelajaran, sehingga perubahan dan perubahan dapat dibuat dan kemajuan dalam sistem pembelajaran. Seperti yang ditunjukkan oleh Gagne dkk (1992) bahwa konfigurasi pembelajaran membantu interaksi belajar individu, di mana siklus memiliki tahap jangka cepat dan panjang. Seperti yang ditunjukkan oleh mereka, sistem pembelajaran terjadi mengingat kondisi belajar: interior dan luar. Kondisi interior: kapasitas dan ketersediaan siswa. Sementara kondisi luar: kursus tindakan ekologis yang direncanakan. Perencanaan kondisi luar adalah hal yang mereka anggap sebagai rencana pembelajaran yang disengaja, dan menerapkan gagasan cara kerangka kerja untuk menangani secara efektif bekerja pada sifat pameran seseorang (Prawiradilaga, 2007).

Seperti halnya penelitian terdahulu yang memberikan suatu pembelajaran yang inovatif dan kreatif dalam pembelajaran di SD yang menyebabkan pembelajaran menjadi menyenagkan dan anak-anak menjadi semangat dalam pembelajaran, seperti pada penelitian yang dilakukan oleh Wijaya dkk (2017) yang membuat desain pembelajaran yag inovatif dan kreatif yang akan membuat pembelajaran lebih menyenagkan dan akan membuat anak lebih bersemangat dalam pembelajaran. Oktafianto, dkk (2019) juga mencoba untuk membuat pembelajaran yang inovatif, peneliti tersebut meyakini bahwa jika semua pembelajaran di desai secara kreatif dan inovatif akan membuat kemampuan anak menjadi meningkat dan pendididkan di Indonesia akn lebih maju, karena semua anak-anak SD tertarik pada hal-hal yang kreatif, sesuai dengan umur mereka yang masih suka dengan hal-hal yang menarik perhatian mereka.

Beberapa peneliti di atas telah mencobakan penelitiannya pada mata pelajaran MTK, dan pada kali ini kami akan mencoba untuk membuat desain pembelajaran yang kkreatif dan invatif pada pembelajaran IPS dan PKn di SD yang nantinya akan menarik perhatian siswa dan akan membuat siswa semangat dalam pembelajaran yang akan mengangkat pendidikan menjadi lebih baik.

Mata pelajaran IPS dan PPKn sama memiliki tujuan yang sesuai untuk membentuk anggota masyarakat yang produktif (menjadi warga negara yang layak), jika IPS Learning lebih menjadikan kerja sama sebagai residen dan motivasi di balik PPN menuju pengembangan karakter. IPS dan PKn bisa diterapkan dalam kehidupan pribadinya. Ini ialah poin utama dalam mencari tahu bagaimana instruktur dapat menyesuaikan kedua mata pelajaran ini untuk mengakomodasi arah mereka.

Masalah yang ditemukan adalah tidak adanya kesiapan atau waktu bagi instruktur untuk memberikan persuasif dan menarik mencari tahu bagaimana untuk memahami. Instruktur merekomendasikan bahwa ia tidak memiliki kesempatan untuk melakukan desain pembelajaran yang signifikan untuk siswa sehingga pada umumnya hanya akan menggunakan guru pendidik dan buku-buku understudy selama waktu yang dihabiskan siswa. Rendahnya perjalanan siswa piknik dicap ketika menanggapi pertanyaan dalam buku, jawaban siswa sebenarnya setua yang berarti siswa hanya mempertahankan materi yang sama persis dalam buku ini. Ini akan mendorong hasil belajar yang rendah. Sesuai penilaian menurut Alfana, M., et al (2015) mengatakan bahwa dukungan imajinatif mempengaruhi pencapaian pembelajaran, dengan asumsi jalannya kerja sama inventif yang rendah maka, pada saat itu, mempengaruhi prestasibelajar siswa.

Pada artikel ini kami akan membahasa secara rinci tentang bagaimana cara mendesain pembelajaran secara kreatif dan inovatif, yang mana dari penelitian sebelumnya sudah banyak yang mambahas cara membuat pembelajaran yang inovatif dan kreatif namun tidak pada mata pelajaran IPS dan PKN di SD sehingga kami akan mencoba untuk membuat desain pembelajaran IPD dan PKN yangkreatif dan inovatif 
5673 Mendesain Pembelajaran PKn dan IPS yang Inovatif dan Kreatif dengan Menggunakan Model Pembelajaran pada Tingkat Sekolah Dasar - Selfi Rahmi Andini, Vianes Muliza Putri, Meila Yufriana Devi, Yeni Erita

DOI: https://doi.org/10.31004/basicedu.v5i6.1760

yang nantinya kan membantu guru dalam membuat desain pembelajaran IPS dan PKNnya di SD, dengan berhasilnya membuat desain pembelajaran yang kreatif dan inovatif akan membuat anak yang belajar terlebih lagi di SD mereka akan semangat dalam pembelajarannya karena cara membelajarkan anak tersebut menarik perhatian mereka.

Artikel ini memuat desain pembelajan IPS dan PKN yang kreatif karena ada beberapa fenomena yang membuat kami memutuskan untuk membuat desain pembelajaran IPS dan PKN yang kreatif, seperti banyaknya guru yang mengeluh tentang rendahnya motivasi dan aktifitas siswa dalam pembelajaran IPS dan PKN yang ada di SD, terlebih lagi dalam hal seperti pembelajaran IPS yang membahas sejarah dan PKN yang membaha tentag hubungan kita dengan hak, kewajiban bahkan menjadi warga Negara yang baik, dan disini anak cendrung kurang bersemangat dalam pembelajaran, bukan karena materinya namun karena guru menyampaikan materinya dengan cara metode ceramah, oleh karena itu kami mencoba membuat suatu desain pembelajaran IPS dan PKN yang akan menarik perhatian serta semangat siswa yang nantinya akan dapat membuat motivasi dan aktivitas siswa menjadi meningkat karena meraka mendapatkan cara pembelajaran IPS dan PKN yang dapat menarik perhatian mereka.

Kami selaku penulis membuat artikel yang menarik ini agar bisa membantu guru dalam mempelajari cara mendesain pembelajaran IPS dan PKN yang nantinya akan membantu dalam meningkatkan kemampuan siswa dalam pembelajaran, yang mana penelitian sebelumnya masih membuat desain pembelajaran yang kreatif dan inovatif dalam mata pelajaran MTK dan sebagainya, namun disini kami akan lebih membahas secara rinci dalam pembelajaran IPS dan PKN karena pembelajaran IPS dan PKN pada umumnya banyak digunakan metode ceramah, akan diubah menjadi lebih kreatif dan inovatif lagi pada artikel ini. Yang nantinya akan membatu membuat semangat dan keaktifan siswa semakin meningkat.

Banyak teori yang menyatakan bahwa pembelajaran IPS dan PKN ini selalu digunakan metode ceramah karena pembelajarannya guru yang menjelaskan kepada siswa, namun pada artikel ini kita akan mencoba untuk membuat pendekatan siswa yang lebih aktif dengan desain yang akan kita gunakan untuk membuat pembelajaran yang inovatif da kreatif, disini siswa yang lebih aktif dalam pembelajaran, karena akan kita hubungakan dengan kehidupan nyata dari siswa, atau lingkungan siswa. Karena jika teori mengatakan ceramah adalah metode yang baik untuk pembelajaran IPS dan PKN buktinya di lapngan banyak siswa yang bosan dengan pembelajaran yang banyak ceramahnya.

Oleh karena itu artikel ini bertujuan untuk membantu menjelaskan cara membuat desain pembelajaran IPS dan PKN yang nantinya akan memancing semangat siswa dalam pembelajaran yang pembelajarannya kreatif dan inovatif.Sehingga akan membuat siswa semangat dalam pembelajarannya dan akan dapat meningkatkan motivasi, aktivitas siswa, sehingga akan membuat pendidikan IPS dan PKN menjadi lebih baik lagi.

\section{METODE}

Peneliti menggunakan pendekatan kualitatif agar selaras dengan perkembangan situasi di lapangan. Data penelitian dengan menggunakan metode ini sangat berkaitan dengan bagaimana cara penulis memberikan penafsiran dari pemahaman penulils dari hal yang ditemukan di lapangan yang sesuai dengan tujuan penelitian (Marwanto, 2021). Peneliti menggunakan pendekatan kualitatif karena, memiliki datanya sesuai dengan fakta sehingga peneliti dapat mengemukakan hal-hal terbaru yang terjadi di lapangan. Maka dapat disimpulkan bahwa desain ini fleksibel dan terbuka. Sedangkan peneliti menggunakan teknik penelitian studi literatur yang mengambil data dari berbagai sumber yang berasal dar jurnal dan buku yang relevan dan mendukung terhadap topik penelitian serta sumber tertulis lainnya. 
5674 Mendesain Pembelajaran PKn dan IPS yang Inovatif dan Kreatif dengan Menggunakan Model Pembelajaran pada Tingkat Sekolah Dasar - Selfi Rahmi Andini, Vianes Muliza Putri, Meila Yufriana Devi, Yeni Erita

DOI: https://doi.org/10.31004/basicedu.v5i6.1760

Partisipan dari penelitian ini adalah peserta didik sekolah dasar dan guru yang bisa mengimplementasikan model-model pembelajaran IPS dan PKn menjadi inovatif serta membuat kemauan peserta didik terhadap belajar menjadi semangat dan sungguh-sungguh. Data diambil dari berbagai macam jurnal yang relevan terhadap topik penelitian ini. Kemudian mencari dan mengambil data yang dibutuhkan secara spesifik terhadap data yang dibutuhkan agar hasilnya akurat. Lalu kemudian dilakukan penginterpretasian guna mendapatkan hasil yang akan membantu mencapai tujuan dari penelitian ini. Penggunaan studi literatur ini berdasar pada sifatnya yang tetap, serta data yang dapat dikumpulkan dengan mudah dan dapat dipertanggung jawabkan karena data yang diambil memiliki keabsahan berdasar pada standar penelitian yang berlaku.

Setelah data yang diperlukan terkumpul, selanjutnya yang dilakukan pengumpulan data yang berasal dari jurnal terkait dengan mendesain pembelajaran IPS dan PKN menjadi pembelajaran yang Inovatif berdasarkan model-model pembelajaran untuk peserta didik dan guru agar suasa pembelajaran menjadi menyenangkan dan bisa meningkatkan hasil dan motivasi peserta didik pada pembelajarannya. Pencarian data ini berlandaskan pada konsep yang diteliti, sehingga data yang diambil terarah, terfokus dan relevan. Selanjutnya dilakukan analisa terhadap topik terkait sehingga terumuskan kesimpulan yang sesuai dengan tujuan penelitian ini. Peneliti mencari data melalui google search engine dengan memasukkan beberapa kata kunci terkait seperti; Desain Pembelajaran Inovatif, Pembelajaran IPS-PKN yang menyenangkan, dan ModelModel pembelajaran yang sesuai dengan pembelajaran IPS dan PKN. Memasukkan kata kunci dengan benar dan tepat ialah poin utama dalam menemukan data yang relevan dalam sebuah penelitian (Andayani, 2020). Keabsahan data dapat terpercaya karena peneliti mendapatkan data dengan mengacu pada ciri-ciri dan unsurunsur dalam situasi yang sangat relevan dengan persoalan yang diteliti.

\section{HASIL DAN PEMBAHASAN}

Sejumlah jurnal dan artikel dianalisis tentang mendesain pembelajaran PKn dan IPS yang Inovatif dan Kreatif dengan menggunakan model pembelajaran pada tingkat sekolah dasar.

\section{Desain Pembelajaran}

Desain pembelajaran adalah rencana untuk sistem pembelajaran tergantung pada persyaratan dan target pembelajaran dan kerangka pengangkutannya sehingga berubah menjadi acuan dalam pelaksanaannya untuk membuat pembelajaran yang menarik dan efektif dengan membatasi kesulitan siswa dalam mendapatkan pembelajaran (Khoerunnisa dkk, 2020). Konfigurasi pembelajaran juga merupakan rencana yang efisien dan mendasar untuk mencapai tujuan pembelajaran (Suharni dkk, 2019). Desain pembelajaran yang hebat, yang ditegakkan oleh kantor yang cukup, dikombinasikan dengan kreativitas instruktur akan membuatnya lebih mudah bagi siswa untuk mencapai target pembelajaran. Selanjutnya asumsi ideal dalam ujian ini, sehingga nantinya pembelajaran IPS dan PKN dalam sistem pembelajaran sepenuhnya berniat membuat penemuan yang membuat siswa dinamis imajinatif dan inventif.

Desain pembelajaran pada dasarnya adalah jenis penggunaan pembelajaran yang ideal dan tepat dari berbagai bagian pembelajaran. Untuk mendapatkan rencana pembelajaran inventif instruktur dapat mengerjakan penggunaan tujuan, materi pembelajaran, media, teknik, penilaian, hingga iklim belajar siswa (Yuwono dkk, 2021). Sejak saat itu konfigurasi pembelajaran akan dibingkai dan menyebabkan siswa mengembangkan keinginan untuk beradaptasi dengan benar-benar dengan alasan bahwa pembelajaran menarik baginya.

Hal ini dipercaya bahwa dengan memanfaatkan model pembelajaran ini sistem pembelajaran dapat menyebabkan siswa menjadi orang yang berguna dengan keadaan mereka saat ini. Model pembelajaran 
5675 Mendesain Pembelajaran PKn dan IPS yang Inovatif dan Kreatif dengan Menggunakan Model Pembelajaran pada Tingkat Sekolah Dasar - Selfi Rahmi Andini, Vianes Muliza Putri, Meila Yufriana Devi, Yeni Erita

DOI: https://doi.org/10.31004/basicedu.v5i6.1760

berfluktuasi dapat bekerja pada jumlah siswa setelah sistem pembelajaran. Model pembelajaran itu sendiri umumnya diatur tergantung pada standar atau hipotesis informasi yang berbeda. Siswa dapat memahami diri mereka sendiri "secara pribadi" yang memiliki cukup untuk berkolaborasi dengan paria untuk memberikan contoh koneksi relasional yang bermanfaat yang didapat dari rencana pembelajaran yang mereka dapatkan di sekolah. Dalam pembelajaran IPS dan PKN menyebabkan karakter siswa berubah menjadi karakter yang cerdik, halus terhadap iklim, sah, mencintai negara dan dapat menjaga NKRI dari segala serangan. Namun, untuk mengharapkan bahwa semua siswa harus memperoleh informasi dari sekolah.

Sejalan dengan penelitian yang dilakukan oleh Ni'matul Khoeriyah dan Mawardi (2019) yang berjudul "Penerapan Desain Pembelajaran Tematik Integratif Alternatif Berbasis Kearifan Lokal untuk Meningkatkan Hasil dan Kebermaknaan Belajar". Peneliti melakukan tindakan inovatif dengan mendesain pembelajaran tematik integratif berbasis kearifan lokal pada pembelajaran. Karena menurut peneliti Pembelajaran tematik integratif dapat membuat siswa aktif dalam proses pembelajaran sehingga peserta didik mendapatkan pengalaman serta dapat menemukan sendiri berbagai pengetahuan sedang dipelajari (Mawardi dkk, 2019).

\section{Pembelajaran IPS dan PKN}

Ips serta PKn ialah pelajaran ini yang terhubung dengan berbagai negara-negara tertentu berkumpul dalam keluarga yang sama sementara bimbingan IPS pada umumnya Indonesia diilustrasikan dalam dua, IPS Education untuk universitas dan IPS mempersiapkan sekolah penting dan asisten. IPS mempersiapkan untuk sekolah yang signifikan dan asisten digambarkan sebagai penataan kembali atau berbagai disiplin sosiologis dan humaniora, sama seperti kegiatan manusia yang signifikan difasilitasi dan disajikan secara cerdas dan intelektual mencerahkan untuk tujuan pendidikan.

Sementara pentingnya pendidikan IPS ialah pilihan disiplin sosiologi dan humaniora seperti latihan manusia mendasar yang dikoordinasikan dan diperkenalkan secara eksperimental dan mental untuk tujuan instruktif, hal yang penting adalah dalam kata perbaikan dan pilihan disiplin ilmu, dll. Penilaian itu menyiratkan bahwa instruksi IPS di universitas dan sekolah dasar dan tambahan memiliki kontras. Hal yang penting adalah dalam hal dipisahkanlement dan penentuan, meskipun mata air penyelidikan materi adalah setara diambil dari disiplin sosiologi (Soemantri, 2001).

PKn ialah pelajaran harus ada untuk peserta didik dimulai dari yang TK,SD, SMP, SMA hingga perguruan tinggi di Indonesia (Tetep dkk, 2019). Pendidikan Kewarganegaraan adalah pelatihan yang bermaksud untuk mendorong kemajuan moral sesuai dengan sisi positif dari Pancasila, khususnya di tingkat program pendidikan sekolah (Daryono, 2011).

Menurut Kemp dkk (1994), esensi dalam desain pembelajaran terdapat 4 komponen, yakni:

1. Ketika menyelesaikan rencana pembelajaran dan mata pelajaran yang akan diinstruksikan, jika tidak terlalu banyak masalah, perhatikan bahwa pencipta benar-benar membuat keadaan belajar yang akomodatif sehingga tujuan pembelajaran dapat dicapai dan siswa dapat merasa hebat dan didorong dalam sistem pembelajaran. Siswa pra-belajar dan belajar dapat dipengaruhi oleh berbagai elemen fisik dan mental, termasuk kelelahan, kelelahan, kelelahan, dan kelelahan. Hal berbeda yang dapat mempengaruhi sifat belajar siswa adalah adanya menunjukkan materi dan gaya penyampaian pendidik dalam menyampaikan materi.

2. Tujuan

Rencana dari tujuan ini terus dibuat tergantung pada kapasitas atau hasil yang harus dimiliki siswa setelah menyelesaikan pembelajaran. Dengan asumsi tujuan atau keterampilan belajar dianggap kacau, tujuan pembelajaran diklasifikasikan sebagai subkompetitif yang tidak sulit dicapai. Rencana pembelajaran, sekali lagi, bergabung dengan kebutuhan siswa dengan kapasitas yang diandalkan untuk didominasi dengan kondisi tertentu dan kondisi tertentu. 
5676 Mendesain Pembelajaran PKn dan IPS yang Inovatif dan Kreatif dengan Menggunakan Model Pembelajaran pada Tingkat Sekolah Dasar - Selfi Rahmi Andini, Vianes Muliza Putri, Meila Yufriana Devi, Yeni Erita

DOI: https://doi.org/10.31004/basicedu.v5i6.1760

3. Metode

Teknik yang diidentifikasi dengan prosedur pembelajaran harus dimaksudkan untuk menjamin kesempurnaan sistem pembelajaran. Strategi adalah cara atau prosedur yang dipandang pas dalam menyampaikan masalah. Perkembangan ini sangat penting dalam rencana pembelajaran karena teknik ini menentukan keadaan belajar yang sebenarnya. Kemudian lagi, kemampuan pencetus pembelajaran juga ditampilkan dalam arti strategi. Dalam ide ini, teknik ini sangat penting untuk metodologi pembelajaran yang mudah.

4. Evaluasi

Gagasan ini melihat penilaian hasil belajar siswa sebagai hal yang vital. Tanda-tanda pencapaian mengambil tujuan dapat dibaca dari evaluasi hasil pembelajaran. Evaluasi secara teratur dilakukan dengan menangani pertanyaan objektif. Penilaian juga harus dimungkinkan dengan menggunakan pengaturan yang tidak seperti perangkat keras persepsi, rapat, survei, dan lain-lain.

Menurut Wahyulestari dkk (2014), desain pembelajaran bertujuan untuk:

1. Mendorong siswa agar terus belajar baik ketika ia dirumah ataupun ketika ia disekolah.

2. Menumbuhkan semangat disiplin siswa dalah pembelajaran.

3. Memunculkan kreativitas siswa melalui tugas dari guru.

4. Membuat diri sendiri untuk jujur saat mengerjakan ujian ataupun praktek.

5. Pantang menyerah dalam mempertahankan nilai bagus di kelasnya

6. Sikap kewirausahaan menjadi muncul dan menekuni bidangnya masing-masing.

Berdasarkan penelitian yang dilakukan oleh Yesi budiarti (2008) yang berjudul "Pengembangan Kemampuan Kreativitas Dalam Pembelajaran IPS", Ada beberapa strategi -strategi pembelajaran IPS yang dapat dilaksanakan untuk mengembangkan kretifitas siswa yaitu Strategy Exposition, bahan ajar disajikan kepada siswa dalam bentuk yang lengkap, dan siswa perlu menguasai bahan ajar. Misalnya, agar siswa memperoleh kemampuan untuk menentukan tanggal dan tanggal kemerdekaan Indonesia, materi yang akan diperoleh sudah siap, penemuan materi dan strategi tertentu, diperlukan materi pembelajaran, sehingga pameran strategi lebih cocok dan Strategy Discovery, Kegiatan ditemukan oleh siswa sendiri melalui berbagai hal. siswa diharapkan mampu menjelaskan peristiwa di balik penciptaan Proklamasi Kemerdekaan, maka strategi penemuan tepat karena mereka perlu menyerap berbagai informasi untuk mencapai keterampilan ini (Budiarti, 2015).

Pada pembelajaran PKn terpadat pada penelitian yang dilakukan oleh Anjar Wijayanti (2018) yang berjudul "Penerapan Model Make a Match untuk Meningkatkan Hasil Belajar Siswa pada Mata Pelajaram PKN Kekas V SDN 04 Kebongembong Kecamatan Pageruyung Kabupaten Kendal TP 2017/ 2018" Bahwa dengan adanya model pembelajaran pada pembelajaran Pkn maka siswa sudah memiliki aktivitas belajar tinggi karena guru sudah mendesain pembelajaran yang menyenangkan dan siswa juga mnegalami peningkatan hasil belajar atau nilai (Wijayanti dkk, 2018).

\section{Teori-teori Pembelajaran dalam Desain Pembelajaran}

Teori pembelajaran berkaitan dengan pengembangan kurikulum atau desain kurikulum. Dengan mempelajari teori belajar, kita dapat mengamati perilaku siswa. Terdapat perbedaan antara pembelajaran dengan teori belajar ,yakni preskriptif dan dekriptif. Preskriptif artinya bisa memperkirakan berlangsungnya sistem pembelajaran yang dilakukan sedangkna deskriptif artinya dapat menggambarkan berlangsungnya proses belajar tersebut. Menurut Asri (2008) ada beberapa teori pembelajaran dalam desain pembelajaran, yaitu: 
5677 Mendesain Pembelajaran PKn dan IPS yang Inovatif dan Kreatif dengan Menggunakan Model Pembelajaran pada Tingkat Sekolah Dasar - Selfi Rahmi Andini, Vianes Muliza Putri, Meila Yufriana Devi, Yeni Erita

DOI: https://doi.org/10.31004/basicedu.v5i6.1760

1. Teori Behaviorisme

Hipotesis pembelajaran behavioristik mengatakan bahwa pembelajaran mengubah perilaku. Spesialis behavioristik mengatakan bahwa sistem pembelajaran terjadi ketika perilaku understudy berubah, dan ketika siswa tidak bereaksi maka perilaku understudy tidak berubah dan ini belum disebut pembelajaran. Terlebih lagi, dalam hipotesis pembelajaran behavioristik menggunakan kerangka disiplin yaitu ketika perilaku understudy tidak berubah. Jika pembelajaran tidak dapat dilanjutkan dan tidak dapat dididik ulang, kerangka kerja yang mengutuk dapat membuat dampak hambatan pada siswa dan membuat siswa bersedia beradaptasi sekali lagi. Misalnya, seorang anak diminta oleh pendidik untuk mengingat augmentasi dan melanjutkan ke hari berikutnya, tetapi anak itu tidak mengingatnya dan didekati untuk tetap berada di depan kelas dan dapat menolak untuk mengingatnya.

2. Teori Kognitivisme

Hipotesis belajar kognitivisme mengungkapkan bahwa belajar adalah penyesuaian pemahaman atau wawasan. Hipotesis pembelajaran ini lebih berkaitan dengan sistem pembelajaran daripada hasil pembelajaran. Model pembelajaran intelektual mengungkapkan bahwa perilaku manusia dikendalikan oleh wawasan dan pemahaman keadaan yang diidentifikasi dengan tujuan pembelajaran. Hipotesis pembelajaran intelektual juga menggarisbawahi bahwa beberapa keadaan mengidentifikasi dengan pengaturan situasi secara keseluruhan. Memisahkan keadaan / subjek menjadi bagian yang lebih sederhana atau memisahkannya dan berkonsentrasi padanya secara independen akan membuat signifikansinya lenyap.

3. Teori Humanistik

Hipotesis humnaistik menerima bahwa belajar memurnikan orang, misalnya menyukai semua yang ada pada manusia. Oleh karena itu, hipotesis pembelajaran humnaistik lebih dinamis daripada bidang ilmu otak pembelajaran dan lebih dekat ke bidang penalaran eksplorasi, hipotesis karakter, dan psikoterapi. Hipotesis ini lebih berkaitan dengan beban belajar daripada sistem pembelajaran. Kursus pelatihan dan pembelajaran tergantung pada pengalaman bermanfaat siswa, yang kemudian digunakan sebagai premis materi. Seperti yang dikatakan salah satu tokoh humanistik Ausubel, pembelajaran adalah penyerapan yang signifikan. Apa yang telah ditemukan diserap dan dianggap berasal dari informasi yang ada sebelumnya. Variabel persuasif dan pertemuan antusias sangat penting dalam berkonsentrasi pada suatu kesempatan.

4. Teori Konstruktivisme

Hipotesis konstruktivis adalah cara berpikir informasi yang menekankan bahwa wawasan kita adalah konsekuensi dari perkembangannya sendiri. Seperti yang ditunjukkan oleh hipotesis ini, informasi dibentuk oleh siswa yang belajar melalui komunikasi dengan materi dan pertemuan baru, informasi yang diperoleh tidak dapat dipindahkan dari instruktur ke understudy, dan substansi materi pembelajaran didikte oleh understudy sendiri.

\section{Macam-macam model desain pembelajaran :}

1. Model ADDIE

Dalam model ini, lima tahap diusulkan oleh singkatannya. a) Analisis: Menganalisis kebutuhan untuk mengenali masalah dan jawaban yang pas untuk menentukan kapasitas siswa b) Desain: Mengidentifikasi kapasitas eksplisit, teknik, bahan, pembelajaran c) kemajuan: Digunakan dalam program pembelajaran Produksi proyek dan materi pelatihan yang harus dilakukan d) Implementasi: Implementasi program pembelajaran dengan merencanakan atau menerapkan rincian program pembelajaran e) Evaluasi: Evaluasi proyek pembelajaran dan penilaian hasil pembelajaran (Pribadi, 2010). 
5678 Mendesain Pembelajaran PKn dan IPS yang Inovatif dan Kreatif dengan Menggunakan Model Pembelajaran pada Tingkat Sekolah Dasar - Selfi Rahmi Andini, Vianes Muliza Putri, Meila Yufriana Devi, Yeni Erita

DOI: https://doi.org/10.31004/basicedu.v5i6.1760

2. Model Dick and Carey

Model ini memiliki 9 tahap dalam pembelajaran, yakni:

Level 1: Identifikasi tujuan pendidikan

Level 2 : Lakukan analisis pelajaran

Level 3 : Identifikasi perilaku penerimaan dan karakteristik pelajar

Level 4 : Tujuan kinerja Menulis

Level 5 : Buat Kriteria Referensi Butir Tes

Level 6 : Pengembangan Strategi Pendidikan

Level 7 : Pengembangan dan Pemilihan Materi Kelas

Level 8: Pengembangan dan Penerapan Penilaian Formatif

Level 9: Pengembangan dan Penerapan Penilaian Komprehensif (Dick and Carey, 2005).

3. Model ASSURE

Model ini dikembangkan oleh Smaldino dkk (2011) ini adalah singkatan dari

a) A: analilyze Learner

b) S: state Objectives

c) S: selct Methods, Media,and Materials

d) U: utilize Materials

e) R:requires Learner Participation

f) E: evaluate and Revise

4. Model Degeng

Model Degeng berisi delapan tahap dalam rencana pembelajaran berkaitan dengan model elaborasi. Artinya, a) pemeriksaan tujuan dan kualitas dalam bidang studi, b) investigasi persyaratan atau aset pembelajaran, c) memecah atribut dalam pembelajaran, d) yang mencirikan alasan dan isi pembelajaran, e) memutuskan teknik alat angkut beban pembelajaran. f) Menetapkan prosedur dan mengawasi pembelajaran, g) Mengatur pembelajaran teknik eksekutif, h) Pengembangan strategi estimasi hasil pembelajaran (Degeng, 1997).

Menurut Suparman (2001), model pembelajaran dipisahkan menjadi tiga tahap: tahap definisi, tahap pemeriksaan kerangka kerja dan kemajuan, dan tahap penilaian. Ada empat faktor yang memiliki efek: (1) Tingkat pemanfaatan, seperti tingkat pondasi instruktif atau tingkat subjek. (2) Menggunakan istilah dalam langkah-langkahnya. (3) Jumlah tahap-tahapnya. (4) Apakah ide dan standar yang digunakan sudah selesai.

\section{Mendesain Pembelajaran IPS dan PKn}

Instruksi adalah upaya sadar untuk bekerja pada informasi, kemampuan, dan perspektif siswa. Pendidikan mengambil bagian penting dalam menciptakan individu yang berwawasan luas, serius dan inventif (Tristiantari, 2016). Untuk mengalahkan hal ini, khususnya dalam pembelajaran kewarganegaraan dan Ilmu Sosial, penting untuk melaksanakan pembelajaran IPS dan PKn yang kreatif.

Pembelajaran IPS menekankan pada pengembangan sikap dan keterampilan sosial pada pengembangan sikap serta keterampilan sosial yang bermanfaat untuk kemajuan diri secara individu ataupun sebagai anggota masyarakat. Untuk mewujudkan sasaran pembelajaran IPS diperlukan berbagai upaya perbaikan. Usaha perbaikan yang dilaksanakan oleh guru adalah mengacu pada student centered. Untuk mengupayakan pengalaman belajar yang menyenangkan dan menantang atau juga diistilahkan dengan PAIKEM (Pembelajaran Aktifik, Inovatif, Kreatif, Efektif dan Menyenangkan), Hal ini dikarenakan pembelajaran ini dibuat menarik, inovatif dan kreatif untuk mmebuat siswa aktif belajar, sehingga tercapai proses pembelajaran yang efektif dalam suasana yang menyenangkan (Rusman, 2010). 
5679 Mendesain Pembelajaran PKn dan IPS yang Inovatif dan Kreatif dengan Menggunakan Model Pembelajaran pada Tingkat Sekolah Dasar - Selfi Rahmi Andini, Vianes Muliza Putri, Meila Yufriana Devi, Yeni Erita

DOI: https://doi.org/10.31004/basicedu.v5i6.1760

Inovasi dalam pembelajaran PKn dapat diperoleh melalui pembelajaran yang kontekstual, karena hal yang kontekstual (mengandung potret riil atau konkrit) akan mempermudah pemahaman siswa. Dengan adanya potret konkrit dimensi sosial-budaya kedalam kelas, diharapkan siswa ketika belajar dalam kenyataan kehidupan yang dilakukan sehari- hari. Pembelajaran dengan inovasi kontektual dalam pembelajaran PKn yang dimaksud adalah pembelajaran dengan menggunakan nilai-nilai keseharian yang relevan dengan PKn (Maftuh, 2015).

Berdasarkan penelitian yang dilakukan oleh Rahayu, G. D. S., \& Firmansyah (2019) dengan judul "Pengembangan Pembelajaran Inovatif Berbasis Pendapingan Bagi Guru Sekolah Dasar" Realita di lapangan menunjukkan bahwa guru sekarang jarang mengembangkan perangkat pembelajaran yang sesuai dengan karakteristik siswanya. Karena guru hanya menggunakan bahan ajar yang ada tanpa membuat bahan ajar sendiri, maka proses pembelajaran yang dilakukan tetap tekstual, guru hanya menjelaskan materi yang sudah ada di buku teks , maka proses pembelajaran yang dilakukan tetap tekstual, guru hanya menjelaskan materi yang sudah ada di buku teks sedangkan siswa hanya mendengarkan dan mencatat penjelasan gurunya, guru memegang kendali dalam pembelajaran. Sebagian besar guru belum pernah menyiapkan perangkat pembelajaran berbasis model pembelajaran yang inovatif. Untuk itu, dalam rangka meningkatkan hasil belajar siswa melalui keterampilan proses, dan lain-lain, maka diperlukan perangkat pembelajaran yang menggunakan model pembelajaran inovatif yang memungkinkan siswa mempelajari secara langsung keadaan alam sekitar. Umumnya, jika aktivitas kelas didominasi oleh aktivitas guru, maka harus diubah menjadi didominasi oleh aktivitas siswa. Ini diubah dari aktivitas memori menjadi aktivitas berpikir. Jadi harus ada perubahan dari belajar menjadi menerima dan belajar menjadi menemukan (Rahayu dkk, 2019).

Sejalan dengan penelitian yang dilakukan oleh Ina Magdalena dkk (2021) dengan judul "Keefektifan Model Desain Pembelajaran Kreatif Inovatif dan Pengaruh Pelaksanaan Evaluasi Formatif" teknik mengatasi proses pembelajaran yang berulang dan bisa membangkitkan motivasi pada siswa, agar tidak bosan dalam proses pembelajaran adalah memberi perubahan atau inovasi dalam pembelajaran seperti contohnya memberi tau pada siswa bahwa dengan zaman yang makin berkembang kita harus mengikutinya sesuai dengan zaman dan dapat juga dilakukan dengan membuat diskusi kelompok (Magdalena dkk, 2021).

Dari berbagai hasil penelitian yang peneliti peroleh dalam berbagai jurnal tentang mendesain pembelajaran IPS PKn yang inovatif dan kreatif dapat dikatakan bahwa dalam proses pembelajaran menggunakan model desain kreatif dan inovatif baik dilakukan, karena dengan dikembangkan model pembelajaran, pembelajaran bersifat aktif dan berpusat pada siswa, hingga siswa ikut berpartisipasi dalam pembelajaran tersebut. Jika siswa telah berpartisipasi dan memancing sifat ingin tahu dan memunculkan kreatifitas pada diri siswa.

\section{KESIMPULAN}

Berdasarkan penelitian dengan pendekatan kualitatif yang bersifat studi literatur yang telah peneliti lakukan pada jurnal.dapat disimpulkan bahwa untuk mendesain pembelajaran ips dan pkn yang inovatif dan kreatif pada siswa SD, oleh karena itu guru diharapkan mampu memberikan inovasi pada pembelajaran yang menarik yang dapat meningkatkan kreatifitas siswa. Sebab dengan adanya inovasi dalam materi ips pkn tersebut dapat mengaktifkan siswa untuk berpikir kreatif sehingga bisa meningkatkan keahlian berpikir kreatif siswa dengan maksimal. Hal ini dapat terlaksana diiringi dengan keahlian guru dalam memfasilitasi siswa kemudian kerja sama siswa serta guru dalam mendesain pembelajaran ips pkn agar tujuan pendidikan terwujud. Adapun model dari desain pembelajaran yang diterapkan ialah Model Addie, Dick and Carey, Assure, Degeng, Pakem dan masih banyak model pembelajaran lainnya. Jadi peneliti menyarankan untuk guru 
5680 Mendesain Pembelajaran PKn dan IPS yang Inovatif dan Kreatif dengan Menggunakan Model Pembelajaran pada Tingkat Sekolah Dasar - Selfi Rahmi Andini, Vianes Muliza Putri, Meila Yufriana Devi, Yeni Erita

DOI: https://doi.org/10.31004/basicedu.v5i6.1760

sebelum pembelajaran membuat sebuah persiapan atau membuat desain jalannya pembelajaran tersebut, khusunya pada pembelajaran IPS dan PKn.

\section{UCAPAN TERIMA KASIH}

Terima kasih kami ucapkan kepada berbagai pihak yang telah membantu peneliti dalam menyelesaikan artikel ini sehingga artikel ini bisa terwujud dan bisa menjadi pedoman bagi peneliti lainnya dalam melakukan riset.

\section{DAFTAR PUSTAKA}

Alfana, M., Dewi, N. R., And S Sukaesih. 2015. "Pengembangan Lembaar Kegiatan Siswa Ipa Tepadu Berbasis Konstruktivisme Tema Eenergi Dalam Kehidupan.” Unnes Science Education Journal 4(1).

Andayani. 2020. "Pentingnya Menulis Kata Kunci Dengan Benar Pada Mesin Pencarian Untuk Melakukan Pencarian Yang Akurat." Jurnal Ilmu Perpustakaan Dan Informasi 4(1): 111.

Asri, Budiningsih. 2008. Teori Belajar Dan Motivasi. Yogyakarta: Universitas Negeri Yogyakarta.

Budiarti. 2015. "Pengembangan Kemampuan Kreativitas Dalam Pembelajaran Ips." Jurnal Pendidikan Ekonomi Um Metro 3(1): 61-72.

Daryono. 2011. Pengantar Pendidikan Pancasila Dan Kewarganegaraan. Jakarta: Rineka Cipta.

Dick, And Carey. 2005. The Sistematic Design Of Instruction. New York: Logman.

Gagne, And Briggs. 1992. Principles Of Instructional Design. New York: Prentice Hall Inc.

I.N.S, Degeng. 1997. Strategi Pembelajaran: Mengorganisasi Isi Dengan Model Elaborasi. Malang: Iptpi.

Kemp, Morrison, And Ross. 1994. Designing Effective Instruction. Ed. Macmillan Collage Publishing Company. New York.

Khoerunnisa, Putri, And Syifa Masyhuril Aqwal. 2020. "Analisis Model-Model Pembelajaran." Fondatia 4(1): 1-27.

Maftuh, Benyamin. 2015. Konsep Dasar Ips. Bandung: Cv Maulana.

Magdalena, I., Shadiqa, C. D., Amanda, M., \& Hasri, T. N. 2021. "Keefektifan Model Desain Pembelajaran Kreatif-Inovatif Dan Pengaruh Pelaksanaan Evaluasi Formatif." Pandawa 3(1): 58-74.

Marwanto, Agung. 2021. "Pembelajaran Pada Anak Sekolah Dasar Di Masa Pandemi Covid 19." Jurnal Basicedu 5(2): 2098-2105.

Mawardi, M., Wardani, N. S., Hardini, A. T. A., \& Kristin, F. 2019. "Model Desain Pembelajaran Tematik Terpadu Kontekstual Untuk Meningkatkan Kebermaknaan Belajar Siswa Sd." Scholaria: Jurnal Pendidikan Dan Kebudayaan 9(1): 48-61.

Oktafianto, K., Kurniawati, E. F., Muzdalifah, L., Arifin, A. Z., Nurfitria, N., Afifah, A., \& Awanda, R. 2019. "Pengembangan Desain Pembelajaran Basic Mathematic Dengan Metode Estafet Kartu." Abdimas Universal 1(2): 24-26.

Prawiradilaga, Dewi Salma. 2007. Prinsip Desain Pembelajaran. Jakarta: Kencana Prenada Media Group.

Pribadi, B.A. 2010. Model Desain Sistem Pembelajaran. Jakarta: Dian Rakyat.

Rahayu, G. D. S., \& Firmansyah, D. 2019. "Pengembangan Pembelajaran Inovatif Berbasis Pendampingan Bagi Guru Sekolah Dasar.” Abdimas Siliwangi 1(1): 17-25.

Rusman. 2010. Model-Model Pembelajaran (Mengembangkan Profesionalisme Guru). Jakarta: Raja Grafindo 
5681 Mendesain Pembelajaran PKn dan IPS yang Inovatif dan Kreatif dengan Menggunakan Model Pembelajaran pada Tingkat Sekolah Dasar - Selfi Rahmi Andini, Vianes Muliza Putri, Meila Yufriana Devi, Yeni Erita

DOI: https://doi.org/10.31004/basicedu.v5i6.1760

Persada.

Smaldino E Sharon, And Dkk. 2011. Teknologi Pembelajaran Dan Media Untuk Belajar, Diterjemahkan Oleh Arif Rahman Dari Istrukturional Technology And Media For Learning. Jakarta: Kencana Prenada Media Group.

Soemantri, Numan. 2001. Menggagas Pembaharuan Pendidikan Ips. Bandung: Pt Remaja Rosdakarya.

Suharni, Leli Tuti, And Farida Fachrudin. 2019. "Pengembangan Desain Pembelajaran Dengan Model Assure Di Sekolah Dasar." Jurnal Basicedu 3(3): 976-82.

Suparman, Atwi. 2001. Desain Instruksional. Jakarta: Depdiknas.

Tetep, And Gunawan. 2019. "Penggunaan Media Film Dalam Meningkatkan Motivasi Belajar Peserta Didik Pada Mata Pelajaran Pendidikan Kewarganegaraan.” Journal Civics And Social Studies 3(1).

Tristiantari, Desia. 2016. "Model Pembelajaran Cooperatif Integrated Reading Composition Berpola Lesson Study Meningkatkan Keterampilan Membaca Dan Menulis.” Jurnal Pendidikan Indonesia 5(2).

Wahyulestari, Mas Roro Diah, And Suwardi Suwardi. 2014. "Desain Pembelajaran "Curi Point" Pada Mata Kuliah Pengembangan Pengajaran Matematika Pendidikan Anak Usia Dini Semester 4 Prodi Pendidikan Anak Usia Dini Universitas Al Azhar Indonesia.” Jurnal Al-Azhar Indonesia Seri Humaniora 1(4): 217.

Wijaya, E. M. S., \& Irianti, N. P. 2017. "Whole Brain Teaching Sebagai Desain Pembelajaran Matematika Yang Kreatif.” Must: Journal Of Mathematics Education, Science And Technology 2(2): 196-207.

Wijayanti, A., Maryadi, M., \& Wijayanti, A. 2018. "Penerapan Model Make A Match Untuk Meningkatkan Hasil Belajar Siswa Pada Mata Pelajaran Pkn Kelas V Sdn 04 Kebongembong Kecamatan Pageruyung Kabupaten Kendal Tp 2017/2018." Jurnal Guru Kita 2(3): 30-38.

Yuwono, Imam, And Mirnawati. 2021. "Strategi Pembelajaran Kreatif Dalam Pendidikan Inklusi Di Jenjang Sekolah Dasar." Jurnal Basicedu 2015-20. Http://Www.Jbasic.Org/Index.Php/Basicedu/Article/View/1347. 